\title{
In-vitro interactions of Ciprofloxacin Hydrochloride with different essential mineral salts and its influence on antimicrobial activity (MIC) of Ciprofloxacin Hydrochloride
}

S. M. Moazzem Hossen ${ }^{1 *}$, Md. Shahidul Islam ${ }^{1}$, Kafil Uddin Mazumder ${ }^{1}$, Md. Salim Hossain ${ }^{2}$, Amitava Chowdhury ${ }^{1}$, Amit kumar Deb ${ }^{1}$, Shafaith Mohammad Shobuj ${ }^{1}$

1. Department of Pharmacy, University of Science \& Technology Chittagong, (USTC).

2. North South University, Dhaka, Bangladesh

\begin{abstract}
Present work describes the interactions of Ciprofloxacin Hydrochloride with different essential mineral salt like Magnesium Sulfate, Manganese Sulfate, Ferrous Sulfate, Zinc Sulfate and Potassium Chloride in an aqueous system at $\mathrm{pH}$ 7.4. This Magnesium Sulfate, Manganese Sulfate, Ferrous Sulfate, Zinc Sulfate and Potassium Chloride are essential trace element. From spectrophotometric study, it has been found that Ciprofloxacin Hydrochloride forms 1:1 complex with Magnesium Sulfate, Manganese Sulfate, Ferrous Sulfate, Zinc Sulfate and Potassium Chloride. Spectral studies helps to detect the initial complexation between drug and mineral salts. Job's plot at 7.4 provides same type of information. An individual antimicrobial study (MIC) of Ciprofloxacin Hydrochloride in 1:1 mixture with Magnesium Sulfate, Manganese Sulfate, Ferrous Sulfate, Zinc Sulfate and Potassium Chloride at $\mathrm{pH} 7.4$ was performed. These studies were carried out by observing the minimum inhibitory concentration (MIC) of the complexes and compared with the parent Cephradine against both Gram negative and Gram positive microorganisms in nutrient broth medium. Study confirms interactions of the Cephradine with Magnesium Sulfate, Manganese Sulfate, Ferrous Sulfate, Zinc Sulfate and Potassium Chloride and the interactions results into change the antimicrobial activity of Cephradine. Result shows that the antimicrobial activity increasing trends in presence of Magnesium Sulfate, Manganese Sulfate, Ferrous Sulfate and decreasing trends in presence of Zinc Sulfate and Potassium Chloride.
\end{abstract}

Key words: Ciprofloxacin Hydrochloride, Job's Plot, Ardon's method, MIC.

\section{Introduction}

Ciprofloxacin hydrochloride $(\mathrm{HCl})$ is a fluoroquinolone antibiotic. It is effective against a wide range of gram positive and gram negative bacteria1, and is most well known for its effectiveness against mycoplasma. Ciprofloxacin $\mathrm{HCl}$ works by interfering with the bacterial enzyme DNA gyrase, an enzyme necessary for bacterial synthesis, replication, and transcription in both the active and non-active growth phases of the bacterial life cycle.

${ }^{*}$ Corresponding Author:

S. M. Moazzem Hossen

Lecturer, Department of Pharmacy,

University of Science \& Technology Chittagong, (USTC).

Foy's Lake, Kulshi, Chittagong 4202. Bangladesh.

Tel. / Mob. +880-01816071263

E-mail: hossen.Pharmacy@hotmail.com 
Ciprofloxacin hydrochloride, USP, a fluoroquinolone, is the monohydrochloride monohydrate salt of 1-cyclopropyl-6-fluoro-1, 4-dihydro-4-oxo-7-(1-piperazinyl)-3-quinolinecarboxylic acid. It is a faintly yellowish to light yellow crystalline substance with a molecular weight of 385.8. Its empirical formula is $\mathrm{C}_{17} \mathrm{H}_{18} \mathrm{FN}_{3} \mathrm{O}_{3} \cdot \mathrm{HCl} \cdot \mathrm{H}_{2} \mathrm{O}$ and its chemical structure is as follows:

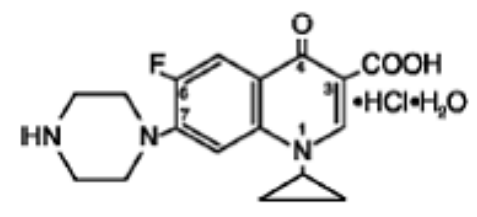

Ciprofloxacin is 1-cyclopropyl-6-fluoro-1,4-dihydro-4-oxo-7-(1-piperazinyl)-3quinolinecarboxylic acid. Its empirical formula is $\mathrm{C}_{17} \mathrm{H}_{18} \mathrm{FN}_{3} \mathrm{O}_{3}$ and its molecular weight is 331.4. It is a faintly yellowish to light yellow crystalline substance and its chemical structure is as follows:

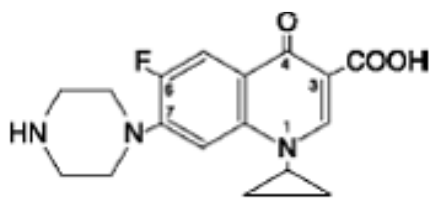

\section{Materials and method}

\section{Materials}

Ciprofloxacin hydrochloride, kind gifts from Medicon laboratories Ltd, Dhaka, Bangladesh. Magnesium Sulphate, Manganese Sulphate, Ferrous Sulphate, Zinc Sulphate and Potassium Chloride were from Merck Itd, Mumbai, India.

\section{Interactions (complexation) study}

\section{Spectral studies:}

Initial detection of complexation of Ciprofloxacin hydrochloride with Magnesium Sulfate, Manganese Sulfate, Ferrous Sulfate, Zinc Sulfate and Potassium Chloride has done from the nature of spectra of pure compounds as well as their 1:1 mixtures in phosphate buffer solution of 7.4 at a fixed concentration $(0.1 \times 10-5) \mathrm{M}$.

\section{Job's spectrophotometric method of continuous variation:}

In this method, series of absorbance of Ciprofloxacin hydrochloride with Magnesium Sulfate, Manganese Sulfate, Ferrous Sulfate, Zinc Sulfate and Potassium Chloride mixture with different molar ratios at $\mathrm{pH} 7.4$ were measured by keeping the total moles constant. The absorbance of Ciprofloxacin hydrochloride and Ciprofloxacin hydrochloride with Magnesium Sulfate, Manganese Sulfate, Ferrous Sulfate, Zinc Sulfate and Potassium Chloride solutions was measured at $270 \mathrm{~nm}$. The observed absorbance of the mixtures of various mole fractions was subtracted from the sum of the values for free Ciprofloxacin hydrochloride and Magnesium Sulfate, Manganese Sulfate, Ferrous Sulfate, Zinc Sulfate and Potassium Chloride. The absorbance difference (D) was then plotted against the mole fractions of drugs in the mixtures. A curve, thus, obtained showed a maximum at a point, which indicated the 
molar ratios of Ciprofloxacin hydrochloride and Magnesium Sulfate, Manganese Sulfate, Ferrous Sulfate, Zinc Sulfate and Potassium Chloride in the complex.

\section{Antibacterial Studies:}

Sample Organisms were employed in these studies were collected from department of microbiology, Chittagong University, Chittagong, Bangladesh. Identification and determination of gram positive and gram negative bacteria were performed.

\section{Estimation of MIC (Turbid metric method to determine MIC): Turbidity Standard:}

To standardize the inoculum's density for a susceptibility test, a $\mathrm{BaSO}_{4}$ turbidity standard, equivalent to a 0.5 McFarland standard was used. $0.05 \mathrm{ml}$ or $50 \mu \mathrm{l}$ of $0.048 \mathrm{M} \mathrm{BaCl}_{2}$ or $1.17 \% \mathrm{~W} / \mathrm{V} \mathrm{BaCl} 2.2 \mathrm{H}_{2} \mathrm{O}$ was added to $9.95 \mathrm{ml}$ of $0.18 \mathrm{M} \mathrm{H}_{2} \mathrm{SO}_{4}$ or $1 \% \mathrm{~V} / \mathrm{V}$ in a screw cap test tube with constant stirring. The correct density of the turbidity standard was verified by using a spectrophotometer. The absorbance was 0.09 at $625 \mathrm{~nm}$. (Normal range is 0.08 to 0.10 at $625 \mathrm{~nm}$ ). Then the tube was capped and sealed tightly to prevent loss of evaporation.

\section{Inoculums Preparation:}

Bacteria were subculture overnight on the nutrient agar medium and a loopful culture from the nutrient agar medium was inoculated into the nutrient broth. The broth was incubated at $37^{\circ} \mathrm{C}$. The turbidity of the growing broth culture was adjusted with sterile saline to obtain turbidity optically comparable to the $0.5 \mathrm{McF}$ arland standard. This results in a suspension containing approximately $108 \mathrm{cfu} / \mathrm{ml}$.

\section{Different concentration antibiotic solution preparation:}

One gram of antibiotic was measured aseptically and was dissolved in $100 \mathrm{ml}$ phosphate buffer. It was mixed vigorously. In this way $104 \mu \mathrm{g} / \mathrm{ml}$ antibiotic solution was obtained. $1 \mathrm{ml}$ from this solution was mixed with $99 \mathrm{ml}$ nutrient broth and made $102 \mu \mathrm{g} / \mathrm{ml}$ solutions. Again from this solution $1 \mathrm{ml}$ was taken and mixed with $99 \mathrm{ml}$ nutrient broth and thus a final concentration $1 \mu \mathrm{g} / \mathrm{ml}$ solution was obtained. By following serial dilution method different concentration of antibiotic solution were prepared. In this test $1 \mu \mathrm{g} / \mathrm{ml}, 2 \mu \mathrm{g} / \mathrm{ml}, 3 \mu \mathrm{g} / \mathrm{ml}$, $4 \mu \mathrm{g} / \mathrm{ml}, 5 \mu \mathrm{g} / \mathrm{ml}, 6 \mu \mathrm{g} / \mathrm{ml}, 7 \mu \mathrm{g} / \mathrm{ml}, 8 \mu \mathrm{g} / \mathrm{ml}, 9 \mu \mathrm{g} / \mathrm{ml}, 10 \mu \mathrm{g} / \mathrm{ml}$ concentration was used. $0.1 \mathrm{ml}$ bacterial suspension which was compared with 0.5 MacFarland solutions was transferred into $9.99 \mathrm{ml}$ saline water. After that, one drop of bacterial suspension containing saline water was inoculated into each different concentration antibiotic containing tubes. This procedure was performed for both gram positive and gram negative bacteria. Then test tubes were incubated at $37^{\circ} \mathrm{C}$ for 48 hours. Finally turbidity was observed visually to determine MIC.

\section{Different concentration of antibiotic and metal complex preparation:}

One gram of antibiotic and $1 \mathrm{gm}$ specific metal salt was measured aseptically and were dissolved in $100 \mathrm{ml}$ phosphate buffer. It was mixed vigorously. By following serial dilution method different concentration of antibiotic solution containing specific metal ion were prepared. In this test $1 \mu \mathrm{g}$ antibiotic and $1 \mu \mathrm{g}$ metal in $1 \mathrm{ml}, 2 \mu \mathrm{g}$ antibiotic and $2 \mu \mathrm{g}$ metal in $1 \mathrm{ml}$ and in such a way $10 \mu \mathrm{g}$ antibiotics and $10 \mu \mathrm{g}$ metal in $1 \mathrm{ml}$ solution was prepared and used in the test. 
$0.1 \mathrm{ml}$ bacterial suspension which was compared with 0.5 McFarland solutions was transferred into $9.99 \mathrm{ml}$ saline water. After that, one drop of bacterial suspension containing saline water was inoculated into each different concentration antibiotic with metal ion containing tubes. In our test we used $\mathrm{MgSO}_{4}, \mathrm{MnSO}_{4}, \mathrm{FeSO}_{4}, \mathrm{ZnSO}_{4}$ and $\mathrm{ACL}$ as the source of metal ion. This same procedure was maintained for each metal. This procedure was performed for both gram positive and gram negative bacteria. Then test tubes were incubated at $37^{\circ} \mathrm{C}$ for 48 hours. Finally turbidity was observed visually to determine MIC.

\section{Measurement of absorbance:}

By using light absorbance technique, the growth of bacteria was measured at $590 \mathrm{~nm}$ in a spectrophotometer. Then the resistant pattern was analyzed by drawing a graph using the chart of absorbance in different concentration of antibiotic.

\section{Results}

\section{Spectral study:}

In spectral studies, it was seen that Ciprofloxacin hydrochloride gives a sharp peak at 270 $\mathrm{nm}$, when the salts (Magnesium Sulfate, Manganese Sulfate, Ferrous Sulfate, Zinc Sulfate and Potassium Chloride) mixed with Cephradine in 1:1 ratio, the intensity of the peak of Ciprofloxacin hydrochloride changes remarkably i.e. absorption characteristics are altered due to interaction but the position of the compound do not shift. Spectral result presented in figure 1.

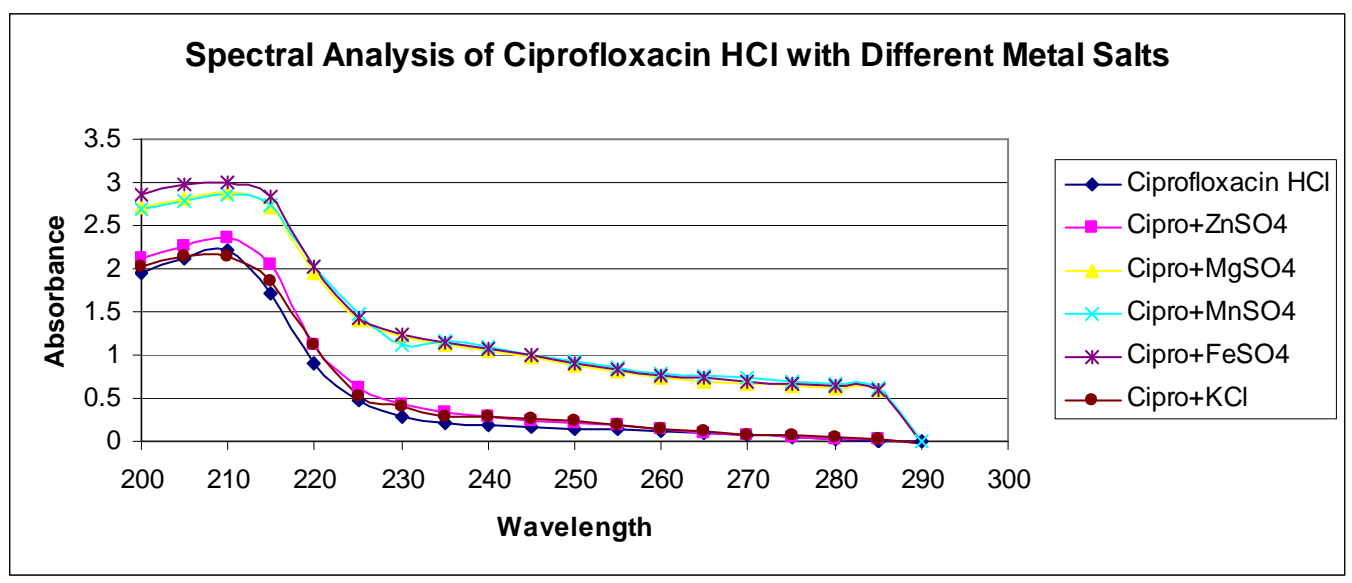

Figure 1: Combined Spectra of Drug \& Drug with different Essential Metal

\section{Study of job's method:}

The molar ratios of the complexes of Ciprofloxacin hydrochloride with metal salts (Magnesium Sulfate, Manganese Sulfate, Ferrous Sulfate, Zinc Sulfate and Potassium Chloride) were estimated by job's method of continuous variation. The observed absorbance values were measured in $\mathrm{pH} 7.4$ at various concentrations $(0.1 \times 10-5$ to $0.9 \times 10-5 \mathrm{M})$ of Ciprofloxacin hydrochloride with metal salts at $270 \mathrm{~nm}$. The Job's plots at 7.4 were obtained by plotting absorbance differences against the mole fraction of the drug Ciprofloxacin hydrochloride, which are presented in Figure 2. 


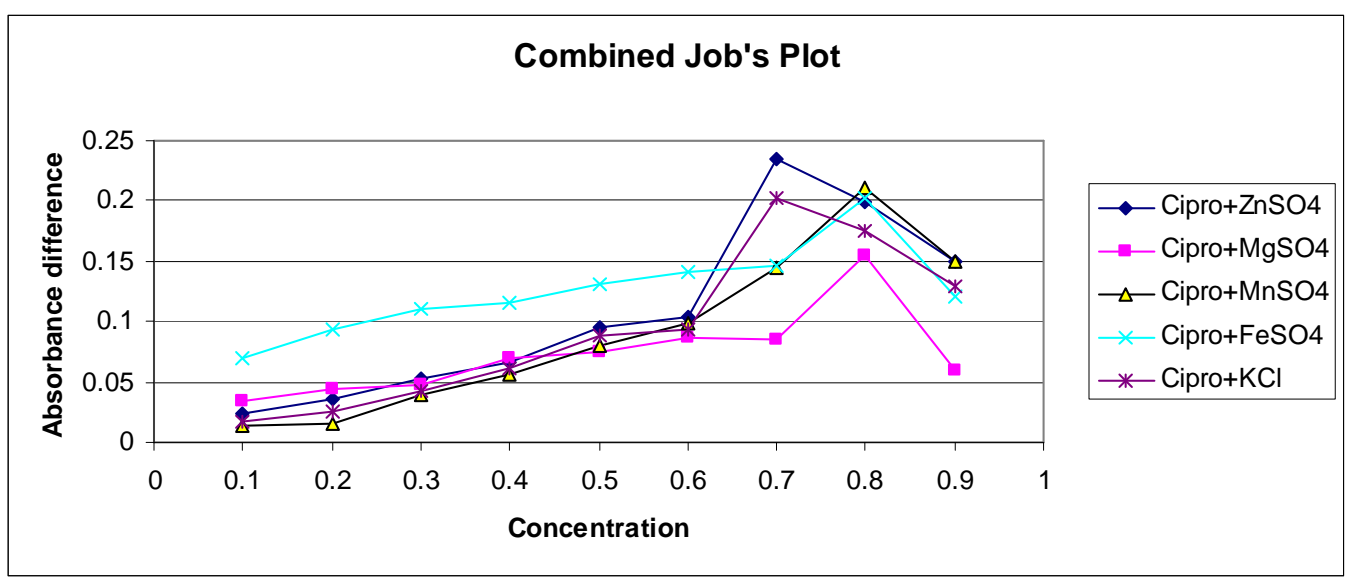

Figure 2: Job's plots for all metal salts after interaction with Ciprofloxacin hydrochloride.

\section{Antibacterial study (MIC determination):}

The MIC of Ciprofloxacin hydrochloride after 1:1 interaction with the Magnesium Sulfate, Manganese Sulfate, Ferrous Sulfate, was found to be decreased for most of the organism as compared to the parent drug. The decreasing trends of MIC were observed for both of the gram positive and gram negative organisms. The intensity of absorbance also decreased remarkably for both gram positive and gram negative organisms.

The MIC of Ciprofloxacin hydrochloride after 1:1 interaction with the Zinc Sulfate and Potassium Chloride was found to be increased for most of the organism as compared to the parent drug. The increasing of MIC was observed for both of the gram positive and gram negative organisms. The intensity of increasing absorbance was also observed. Table: $1 \mathrm{~A} \&$ 1B shows absorbance of the growth and Figure: $3 \mathrm{~A} \& 3 \mathrm{~B}$ shows the comparison.

Table 1A: Absorbance of the growth of Gram Positive Bacteria containing dilution

\begin{tabular}{ccccccc}
\hline $\begin{array}{c}\text { Conc. of Cipro. } \\
\mathrm{HCl} \mu \mathrm{g} / \mathrm{ml}\end{array}$ & Cipro. & $\begin{array}{c}\text { Cipro + } \\
\text { MgSO4 }\end{array}$ & $\begin{array}{c}\text { Cipro }+ \\
\text { MnSO4 }\end{array}$ & $\begin{array}{c}\text { Cipro }+ \\
\text { FeSO4 }\end{array}$ & $\begin{array}{c}\text { Cipro }+ \\
\text { ZnSO4 }\end{array}$ & $\begin{array}{c}\text { Cipro }+ \\
\mathrm{KCl}\end{array}$ \\
2 & 0.552 & 0.297 & 0.297 & 0.175 & 0.636 & 0.719 \\
3 & 0.502 & 0.19 & 0.255 & 0.155 & 0.613 & 0.609 \\
4 & 0.47 & 0.136 & 0.231 & $\mathrm{NG}$ & 0.487 & 0.601 \\
5 & 0.427 & $\mathrm{NG}$ & 0.173 & $\mathrm{NG}$ & 0.437 & 0.491 \\
6 & 0.405 & $\mathrm{NG}$ & 0.135 & $\mathrm{NG}$ & 0.421 & 0.465 \\
7 & 0.384 & $\mathrm{NG}$ & $\mathrm{NG}$ & $\mathrm{NG}$ & 0.401 & 0.345 \\
8 & 0.296 & $\mathrm{NG}$ & $\mathrm{NG}$ & $\mathrm{NG}$ & 0.271 & 0.219 \\
9 & $\mathrm{NG}$ & $\mathrm{NG}$ & $\mathrm{NG}$ & $\mathrm{NG}$ & 0.198 & 0.156 \\
10 & $\mathrm{NG}$ & $\mathrm{NG}$ & $\mathrm{NG}$ & $\mathrm{NG}$ & $\mathrm{NG}$ & 0.125 \\
& $\mathrm{NG}$ & $\mathrm{NG}$ & $\mathrm{NG}$ & $\mathrm{NG}$ & $\mathrm{NG}$ & $\mathrm{NG}$ \\
\hline
\end{tabular}

$N G=$ No Growth was Observed visually. 


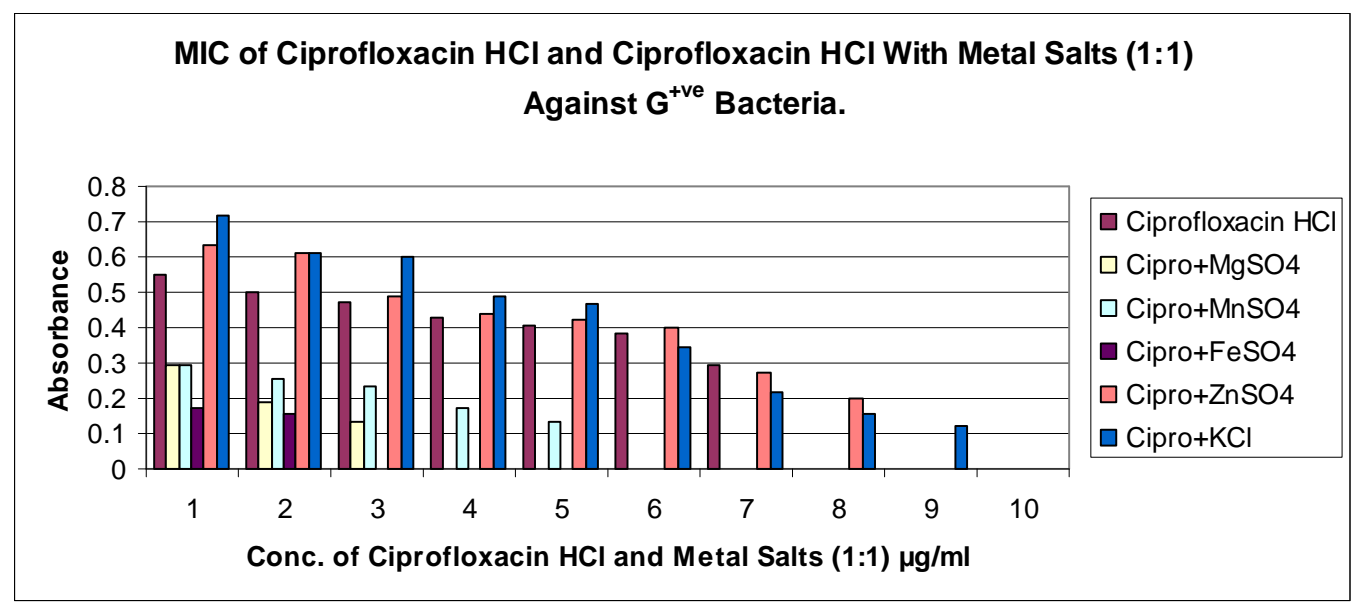

Figure: $3 \mathrm{~A}$ shows comparison of variation of the growth of Gram Positive bacteria after using different metal with antibiotic

Table 1B: Absorbance of the growth of Gram Negative Bacteria containing dilution

\begin{tabular}{ccccccc}
\hline $\begin{array}{c}\text { Conc. of } \\
\text { Cipro. } \\
\mu \mathrm{g} / \mathrm{ml}\end{array}$ & Cipro. & $\begin{array}{c}\text { Cipro }+ \\
\text { MgSO4 }\end{array}$ & $\begin{array}{c}\text { Cipro+ } \\
\text { MnSO4 }\end{array}$ & $\begin{array}{c}\text { Cipro }+ \\
\text { FeSO4 }\end{array}$ & $\begin{array}{c}\text { Cipro }+ \\
\text { ZnSO4 }\end{array}$ & $\begin{array}{c}\text { Cipro+ } \\
\text { KCl }\end{array}$ \\
\hline 1 & 0.615 & 0.412 & 0.396 & 0.151 & 0.865 & 0.751 \\
2 & 0.601 & 0.321 & 0.351 & 0.119 & 0.723 & 0.743 \\
3 & 0.557 & 0.175 & 0.276 & NG & 0.639 & 0.679 \\
4 & 0.535 & NG & 0.249 & NG & 0.511 & 0.512 \\
5 & 0.457 & NG & NG & NG & 0.476 & 0.413 \\
6 & 0.391 & NG & NG & NG & 0.336 & 0.327 \\
7 & 0.322 & NG & NG & NG & 0.237 & 0.254 \\
8 & $\mathrm{NG}$ & NG & NG & NG & 0.124 & 0.147 \\
9 & $\mathrm{NG}$ & $\mathrm{NG}$ & $\mathrm{NG}$ & $\mathrm{NG}$ & $\mathrm{NG}$ & 0.129 \\
10 & $\mathrm{NG}$ & $\mathrm{NG}$ & $\mathrm{NG}$ & $\mathrm{NG}$ & $\mathrm{NG}$ & $\mathrm{NG}$ \\
\hline
\end{tabular}

$\mathrm{NG}=$ No Growth was Observed visually

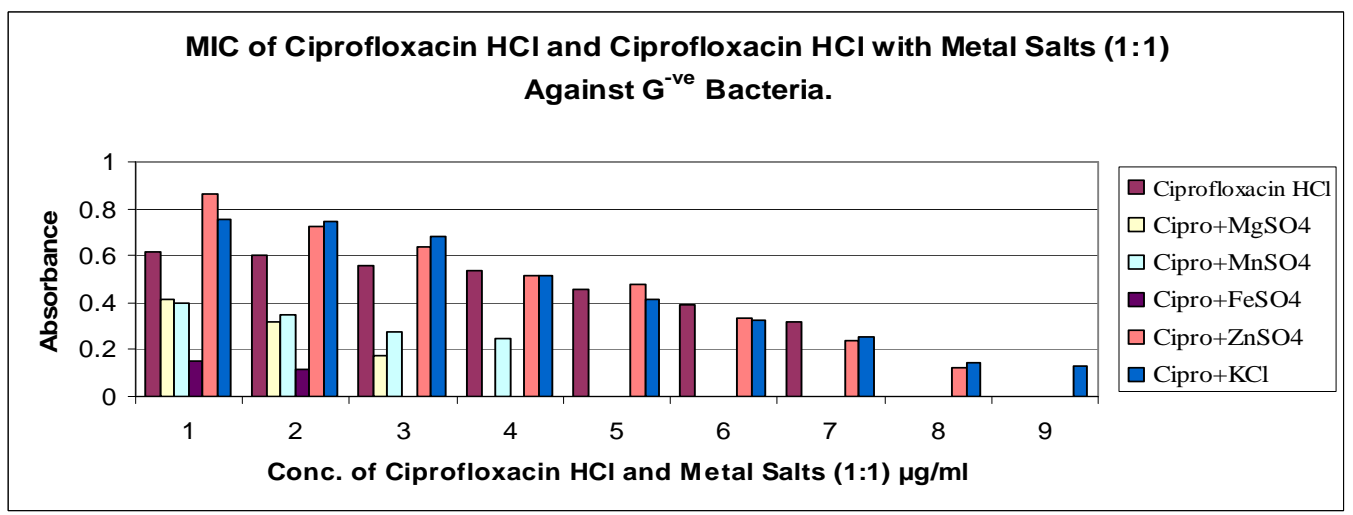

Figure 3B shows comparison of variation of the growth of Gram Negative bacteria after using different metal with antibiotic. 


\section{Discussion}

In the present work, the interaction of an important antibiotic, Ciprofloxacin hydrochloride with Magnesium Sulfate, Manganese Sulfate, Ferrous Sulfate, Zinc Sulfate and Potassium Chloride has been studied in the aqueous system at $\mathrm{pH} 7.4$ by a variety of physical method like inspection of spectral behavior, Job's method of continuous variation plots by Spectrophotometry. From spectral study, it has been seen that Ciprofloxacin hydrochloride gives a sharp peak at $270 \mathrm{~nm}$. When Magnesium Sulfate, Manganese Sulfate, Ferrous Sulfate, Zinc Sulfate and Potassium Chloride salt mixed with Cephradine at 1:1 ratio, the intensity of the peak of Ciprofloxacin hydrochloride changes remarkably, i.e. absorption characteristics are altered due to interaction but the position of the compound do not shift. Job's plot has given the molar ratio of complexes of Ciprofloxacin hydrochloride and with metal salts. At pH 7.4 Ciprofloxacin hydrochloride forms strong 1:1 complexes with metal salts indicated as ' $\wedge$ ' shaped curves. These curves may indicate strong kinetics of complexation between Ciprofloxacin hydrochloride \& metal salts. After interactions the antimicrobial property may change. Antimicrobial activity determinations of Ciprofloxacin hydrochloride after interaction with metal salts were performed to quantify the change.

The determination minimum inhibitory concentration (MIC) of Ciprofloxacin hydrochloride was performed after 1:1 interaction with Magnesium Sulfate, Manganese Sulfate, Ferrous Sulfate, Zinc Sulfate and Potassium Chloride. Result was found to be decreased in minimum inhibitory concentration (MIC) for most of the organism as compared to the parent drug in presence of Magnesium Sulfate, Manganese Sulfate, and Ferrous Sulfate. The decreasing trends in the MICs for both of the gram positive and gram negative organisms. That means the antimicrobial activity of Ciprofloxacin hydrochloride increased in presence of Magnesium Sulfate, Manganese Sulfate, and Ferrous Sulfate. Result also was found to be increased in minimum inhibitory concentration (MIC) for most of the organism as compared to the parent drug in presence of Zinc Sulfate and Potassium Chloride. The increase in the MICs for both of the gram positive and gram negative organisms was observed. That means the antimicrobial activity of Ciprofloxacin hydrochloride decreased in presence of Zinc Sulfate and Potassium Chloride.

\section{Conclusion}

Finally it can be concluded that the antimicrobial activity is higher for $1: 1$ complexes of Ciprofloxacin hydrochloride with Magnesium Sulfate, Manganese Sulfate, and Ferrous Sulfate than that of Cephradine alone. As a result, the intake of Ciprofloxacin hydrochloride with Magnesium Sulfate, Manganese Sulfate salt or Magnesium, Manganese and Ferrous complexes of Ciprofloxacin hydrochloride or the concurrent therapy can increase the antimicrobial activity of Ciprofloxacin hydrochloride. It is also observed that antimicrobial activity is lower for Ciprofloxacin hydrochloride complexes with Zinc sulfate and Potassium chloride. So we must be careful during concurrent therapy with Magnesium Sulfate, Manganese Sulfate, Ferrous Sulfate, Zinc Sulfate and Potassium Chloride.

\section{References}

1. Brithsh Pharmacopoeia (2002). CD Ver. 6, the Stationary Office London. P. Cefradine, pp.1-4.

2. United State Pharmacopoeia (USP). 
3. Ryan, C.W., Simon, R.L. and Van Heyningen, E.M. (1969). Chemistry of cephalosporin antibiotics 13-desacetoxycephalosporins. The synthesis of cephalexin and some analogs. J.Med. Chem. 12(2): 310-313.

4. John H. Block, Edward B. Roche, Taito O. Soine, Charles O.Wilson; Inorganic Medicinal and Pharmaceutical Chemistry, India, 1986, 1, 213-234.

5. Lambert, H.P. and O'Grady, F.W. (1992). Antibiotic and Chemotherapy, 6th ed. Churchill, Livingstone, Medical Division of Longman group U.K. Ltd., pp.72-135, 191230.

6. Fong, I.W., Engelking, E.R. and Kirby, W.M.M. (1976). Relative inactivation by staphylococcus aureus of eight cephalosporin antibiotics. Antimicrob. Ag. Chemother. 9(6): 939-944.

7. Basker, M.J., Endmondson, R.A. and Sutherland, R. (1980). Comparative stabilities of penicillins and cephalosporins to staphylococcal beta lactamase and activities against staphylococcus aureus. J. Antimicrob. Chemother. 6(3): 333-341.

8. Hamilton-Miller, J.M.T. (1974). Comparative activity of ampicillin and seven cephalosporins against group D streptococci. J. Clin. Path. 27(10): 828-831.

9. Busch, D.F., Kureshi, L.A., Sutter, V.L. and Finegold, S.M. (1976). Susceptibility of respiratory tract anaerobes to orally administered penicillins and cephalosporins. Antimicrob. Agents Chemother. 10(4): 713-720.

10. McGowan, J.E. Jr., Garner, C., Wilcox, C. and Finland, M. (1974). Antibiotic susceptibility of gram-negative bacilli isolated from blood cultures. Results of test with 35 agents and strains from 169 patients at Boston city Hospital during 1972. Amer. J. Med. 57(2): 225-238.

11. Bill, N.J. and Washington, J.A.H. (1977). Comparison of in vitro activity of cephalexin, cephradine and cefaclor. Antimicrob. Agents Chemother. 11(3): 470-474.

12. Wise, R., Andrews, J.M., Dean, S. (1979). A pharmacological and in vitro comparison of three oral cehphalosporins. J. Antimicrob. Chemother. 5(5): 601-607.

13. Phillips, I., King, A., Warren, C. and Watts, B. (1976). The activity of penicillins and eight cephalosporins on Neisseria gonorrhoeae. J. Antimicrob. Chemother. 2: 31.

14. Goldstein, E.J.C., Kwork, Y.Y. and Sutter, V.L. (1983). Susceptibility of Gardnerella vaginalis to cephradine. Antimicrob. Agents Chemother. 24(3): 418-419.

15. Messmer, J.C., Lecaillon, T.E., Bon, F. and Golg, H. (1983). In vitro comparison of the antibacterial activity of 1 st, 2 nd and 3rd generation cephalosporins. Sem. Hosp. 59(34): 2389-2392.

16. Arthur Israel Vogel. Textbook of Quantitative Inorganic Analysis. 4th Edition. Longman (1978).

17. S. M. Moazzem Hossen, Md. Raihan sarkar, Md. Shahidul Islam, Abanti Barua, Mohammad Kamal Hossain, Md. Sahamir Hossain. (2012). In-vitro interaction study of Cephradine with different essential mineral salts and its influence on antimicrobial activity (MIC) of Cephradine. Int. J. Pharmaceutical and Life Sciences. 